\title{
Effect of Service Quality and Product Quality To Corporate Image, Customer's Satisfaction and Customer's Trust
}

\author{
Rita Alfin ${ }^{1}$, Taher Alhabsji ${ }^{2}$, Umar Nimran ${ }^{2}$, Suharyono $^{2}$ \\ ${ }^{l}$ PhD Student, Faculty of Administration Science, University of Brawijaya \\ ${ }^{2}$ Faculty of Administration Science, University of Brawijaya
}

\begin{abstract}
This study aims to examine and explain the effect of the variable service quality and product quality to the company's image, satisfaction and trust. The research was conducted in the area of East Java province which consists of 38 cities / counties, the individual customers who have an active savings bank accounts owned BNI in East Java province. Further sampling Tabungan Plus customers (Taplus) BNI to 4 cities; Surabaya, Malang, Kediri, and Jember done proportionally area (proportional sampling) so that the research sample was 149 people. The analysis tools are Structural Equation Modeling (SEM) to determine the pattern and effect relationships between variables in sequence, i.e. endogenous and exogenous variables. In the SEM analysis, structural equation models, in principle, a multivariate analysis that describes the application of several models simultaneously (Augusty, 2002). The results of the study explained that there is a significant effect between the variables of service quality to the image of the company (0.307) and customer satisfaction (0.307), corporate image, product quality (0.433) and customer value (0.351), the company's image against consumer trust (0.329), the value customer to customer satisfaction (0.478) as well as customer satisfaction with customer trust (0.408).
\end{abstract}

Keywords: Structural Equation Modeling (SEM), service quality, product quality, corporate image, satisfaction, trust

\section{BACKGROUND}

Development of Indonesia's economic performance in 2010, the better to $6.1 \%$, higher than the growth in 2009 of only $4.6 \%$ (Bank Indonesia, 2011). economic growth is supported by a more balanced sources of growth, as reflected on the role of investment and exports are rising.

On the banking side, credit growth remains high with working capital loans as the main driver, while consumer loans are still going to grow stronger due to the strength of household consumption. Meanwhile, in line with the high growth in investment, credit growth accelerated investment in 2011 continues. Policies aimed at enhancing the resilience of banks to shore up the bank's performance, strengthen competitiveness, and also stem the crisis shock.

East Java Province is one of the richest provinces in Indonesia, with a GDP per capita of Rp 16.7 million (nominal) in 2008. Average economic growth in East Java to 5.2 percent between 2001 and 2009, equivalent to a growth rate of the national average. East Java Province pretty big role and can greatly influence which is about 15 per cent of Indonesia's economy.

In general, efforts to improve the service quality of an organization starting from the high commitment of the management of the organization along with individual employee performance improvement, so that every organization to pay more attention to the performance of individual employees. With good internal service quality will lead to employee satisfaction in their work, which ultimately fosters attitudes and productive employee behavior that ultimately affect the quality of external services.

Based on the phenomenon of banks in East Java Province, and by looking at the importance of the customer in the marketing concept makes many academics focus their research on the topic or proximity relationships with customers. The focus of the organization or company relationships with customers are generally concerned about the quality of the service, to customer satisfaction.

With banking circumstances indicate that the bank - the giant private banks have the potential to overtake the ratings or performance of state-owned banks (Limited). This study focused on the Bank Negara Indonesia (BNI) with a case study on a customer of Tabungan Plus (Taplus) East Java Province. Selection of study subjects is mainly due to that as a government-owned bank, Bank Negara Indonesia (BNI) is ranked third by the bank in the acquisition of customer funds.

The results of this study are expected to contribute a comprehensive related to Service quality and Product quality greatly affect the company's image, Satisfaction, Value and Trust in the banking financial services institution especially Bank Negara Indonesia (BNI) in East Java for material performance improvement, so that Bank Negara Indonesia (BNI) to follow the achievements of Bank Mandiri and Bank Rakyat Indonesia (BRI). 


\section{Theoretical Review}

In the concept of services marketing, Kotler (1994) explains that not only required external marketing but also internal marketing. Internal marketing describes the work carried out by the organization in training, to meet the needs, reward and motivate employees so that employees feel satisfaction in work. It is important for the employee to do a good job in providing satisfactory services to external customers. The problem occurs usually starts from internal sources, i.e. how the quality of bank employees providing services to customers. The expected value of the customer it is a determinant of satisfaction (Lai et al., 2009; Kuo and Ye, 2009, and Hu et al., 2009).

Researchers who support the influence between variables such as:

1. Research Helgesen, Havold, and Nesset (2010) which resulted in the conclusion that the image is directly significant effect on loyalty. Corporate image is directly significant effect on satisfaction. These results can be said that the image of the company influence either directly or indirectly to loyalty. Meanwhile, the image of the machine does not significantly affect loyalty, but significant effect on store image and contentment.

2. Research Kuo and Ye (2009) to test hypotheses which states that service quality and image of the institution positive effect on customer satisfaction, positive effect on loyalty. Furthermore, customer satisfaction is also a positive effect on loyalty.

3. Research Hu, Kandampully, and Juwaheer (2009) with the results of the testing indicate that the positive effect on the service quality perceived value. Perceived value positive effect on behavioral intentions. Positively influence service quality to customer satisfaction. Perceived value positive effect on customer satisfaction. Positive effect on service quality corporate image. Perceived value positively on the image of the company. Customer satisfaction has a positive influence on the company's image. Corporate image positive influence behavioral intentions or loyalty. While the results of this study reject the hypothesis that the perceived quality positive influence on behavioral intentions or loyalty.

4. Lai, et al., (2009) which states that service quality significantly influence the value, image, and loyalty. Image significant effect on customer satisfaction, value, and loyalty.

5. Naeem et al., (2009) which resulted in the conclusion that the service quality generally positive effect on customer satisfaction.

6. Research Pollack (2009) which resulted in the conclusion that the service quality generally positive effect on customer satisfaction, and further influence positively of loyalty.

7. Ismail et al., (2009) conducted a study with the results of the analysis of data obtained from 102 samples of academic staff is that the expected value of a moderating influence of service quality on customer satisfaction. (Responsiveness $\mathrm{x}$ perceived value) was not significantly negative effect on customer satisfaction. (Assurance x perceived value) was also not significant negative effect on customer satisfaction. (Empathy x perceived value) significant positive effect on customer satisfaction.

8. Research Vesel, and Zabkar (2009) with the results obtained indicate that the program positively affects the quality of customer loyalty. Customer satisfaction has a positive effect on customer loyalty. Program quality positive influence on customer satisfaction. Quality of personal interactions positive effect on customer satisfaction.

9. Research Deng et al., (2009) with the results obtained indicate that the positive effect of customer satisfaction on customer loyalty. Positively affect customers' trust on customer loyalty. Positive effect on customer trust customer satisfaction. Quality Service positive influence customer satisfaction. Positive effect on the value of customer satisfaction. Switching costs positively affect customer loyalty.

10. Research Hutchinson et al., (2009) with the results obtained indicate that the positive effect on customer satisfaction. Positive influence on the service quality expected equity. Positive effect on equity value. Equity positive effect on customer satisfaction. Value of a positive influence on loyalty (intention). Customer satisfaction has a positive influence on loyalty (intention). Value of a positive influence on loyalty (word of mouth). Satisfaction positive effect on loyalty (word of mouth).

\section{Materials And Methods}

Based on the theoretical foundation, then the study will examine and analyze the quality of the product and assessing five indicators of SERVQUAL are tangible, reliability, responsiveness, assurance and empathy toward corporate image, customer satisfaction, customer value, customer trust. Customer case studies on Tabungan Plus (Taplus) Bank Negara Indonesia (BNI) in the province of East Java.

The research was conducted on individual customers who have an active savings bank accounts owned BNI in East Java province. Customer data Bank Negara Indonesia (BNI) in 4 (four) branches from each City / County that serve a population of 166,344 people and is conditional population amounting to 157,435 people. Further sampling Tabungan Plus customers (Taplus) BNI to 4 cities; Surabaya, Malang, Kediri, and Jember done proportionally area (proportional sampling) sample obtained was 149 people. 
Analysis technique in this research is Structural Equation Modeling (SEM). In accordance with the objectives of the study were carried out can be categorized as an explanatory research, i.e. research that aims to find an explanation of the causal relationships between variables or the influence of other variables through hypothesis testing (Umar, 2004). The variable in this study is the variable service quality, Products Quality, Corporate Image, Customer Satisfaction, and Customer Value. SEM analysis model based on the following conceptual framework:

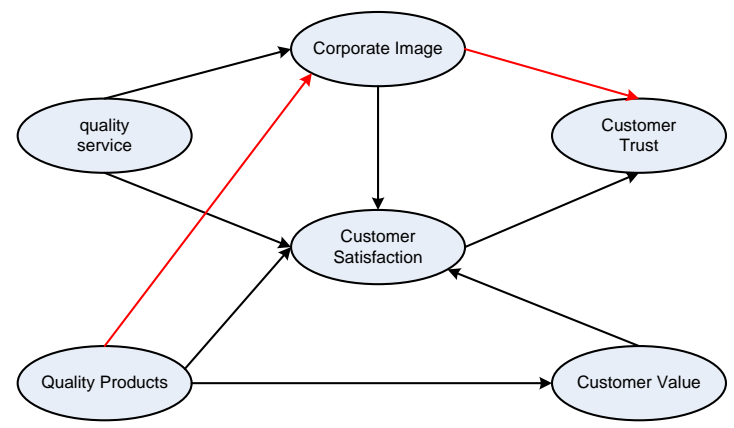

Figure 1: Conceptual Framework

\subsection{Testing Instrument}

\section{Results}

The following tables are presented testing the validity and reliability of the research instrument for each variable. Table 1 shows that all correlation values of each indicator and the items were above 0.3. Thus, the overall indicators and items have valid questions. While the Cronbach alpha values obtained from above 0.6 for all the variables so that the data can be concluded that the instrument was valid and reliable research.

Table 1: Validity and Reliability Instruments

\begin{tabular}{|c|c|c|c|c|c|c|}
\hline Variable & \multicolumn{2}{|c|}{$\mathrm{X} 1$} & \multicolumn{2}{|c|}{$\mathrm{X} 2$} & \multicolumn{2}{|c|}{$\mathrm{X3}$} \\
\hline 1 & X1.1 & 0.582 & $\mathrm{X} 2.1$ & 0.572 & X3.1 & 0.641 \\
\hline 2 & & 0.605 & & 0.713 & & 0.598 \\
\hline 3 & & 0.475 & $\mathrm{X} 2.2$ & 0.694 & X3.2 & 0.669 \\
\hline 4 & $\mathrm{X} 1.2$ & 0.626 & & 0.555 & & 0.609 \\
\hline 5 & & 0.547 & $\mathrm{X} 2.3$ & 0.718 & X3.3 & 0.692 \\
\hline 6 & X1.3 & 0.517 & & 0.633 & X3.4 & 0.621 \\
\hline 7 & & 0.605 & & & & 0.609 \\
\hline 8 & X1.4 & 0.596 & & & & \\
\hline 9 & & 0.584 & & & & \\
\hline 10 & & 0.523 & & & & \\
\hline 11 & & 0.477 & & & & \\
\hline 12 & X1.5 & 0.576 & & & & \\
\hline 13 & & 0.547 & & & & \\
\hline Cronbach & \multicolumn{2}{|c|}{0.831} & \multicolumn{2}{|c|}{0.725} & \multicolumn{2}{|c|}{0.752} \\
\hline Variable & \multicolumn{2}{|c|}{$\overline{X 4}$} & \multicolumn{2}{|c|}{$\mathrm{X5}$} & \multicolumn{2}{|c|}{$\mathrm{X6}$} \\
\hline 1 & \multirow[t]{2}{*}{$\mathrm{X} 4.1$} & 0.752 & X5.1 & 0.640 & X6.1 & 0.623 \\
\hline 2 & & 0.754 & & 0.476 & & 0.555 \\
\hline 3 & $\mathrm{X} 4.2$ & \multirow{2}{*}{$\begin{array}{l}.804 \\
0.642\end{array}$} & $\mathrm{X} 5.2$ & 0.721 & X6.2 & 0.560 \\
\hline 4 & & & & 0.637 & & 0.591 \\
\hline 5 & & & X5.3 & 0.619 & X6.3 & 0.564 \\
\hline 6 & & & & 0.739 & & 0.660 \\
\hline 7 & & & X5.4 & 0.522 & X6.4 & 0.704 \\
\hline 8 & & & & 0.592 & & 0.454 \\
\hline 9 & & & X5.5 & 0.693 & $\mathrm{X} 6.5$ & 0.659 \\
\hline 10 & & & & 0.665 & & 0.511 \\
\hline Cronbach & \multicolumn{2}{|c|}{0.724} & \multicolumn{2}{|c|}{0.831} & \multicolumn{2}{|c|}{0.785} \\
\hline
\end{tabular}




\subsection{Testing Assumptions in SEM}

An assumption that must be met prior to SEM analysis is the assumption of normality, absence of outliers, and linearity. Multivariate normality assumption was tested with the help of software AMOS 6 . Normality Test results obtained critical value ratio of -5.665 to the critical value $\mathrm{Z}$ count for alfa $5 \%$ is equal to 1.96. Since the absolute value of a multivariate CR for 5.665> 1.96 then the assumption of multivariate normality was not met. However, referring to the central limit theorem, that if the research involves a large number of samples $(n=149)$, the sample data can be treated as data population normality of the data so that the problem can be considered critical or negligible.

The investigation of outliers can be seen with the Mahalanobis distance (Md). Mahalanobis distance was evaluated using the value of 151.883 . Of the Mahalanobis distance to the most distant point of observation is a respondent to the 149 with the value $\mathrm{Md}=60.735$. When compared with the value of 151.883 points to the value of Md-149 $<151.883$, it was concluded that all of the point of observation is not an outlier.

Testing the assumption of linearity was conducted by Curve Fit. Linearity test results showed all significant linear model for the $\mathrm{Sig}<0.05$ thus concluded that the assumption of linearity was met.

\subsection{Goodness of Fit SEM Model}

Test results overall goodness of fit model, according to the results of SEM analysis, to determine whether the hypothetical models supported by empirical data, are given in Table 2 below:

Table 2: Goodness of Fit Overall Model

\begin{tabular}{|l|c|c|}
\hline \multicolumn{1}{|c|}{ Criteria } & Cut-of value & Result \\
\hline Chi Square & Small & 232.474 \\
\hline p-value & $\geq 0.05$ & 0.352 \\
\hline CMIN/DF & $\leq 2.00$ & 1.033 \\
\hline GFI & $\geq 0.90$ & 0.892 \\
\hline AGFI & $\geq 0.90$ & 0.892 \\
\hline TLI & $\geq 0.95$ & 0.990 \\
\hline CFI & $\geq 0.95$ & 0.992 \\
\hline RMSEA & $\leq 0.08$ & 0.015 \\
\hline
\end{tabular}

From Table 2 shows 6 of 8 criteria have been met the threshold criteria (cut of value) so that the feasibility of the model obtained is feasible.

\subsection{Measurement Model}

Factor loading values indicate the weight of each indicator as a measure of each latent variable. Indicators with the greatest factor loading indicates that the indicator variable as a measure of the strongest (dominant). The results of measurement model are presented in Table 3.

Based on Table 3, the variable service quality (X1) Tangibles fifth indicator (X1.1), Reliability (X1.2), Responsiveness (X1.3), Empathy (X1.4), and Assurance (x1.5) was significantly variables measuring Service quality (X1). From the value of loading factor, it is known that Tangible indicators (X1.1) is the strongest indicator variable measuring Service quality (X1).

In the variable Product Quality (X2) Product Breadth third indicator (X2.1), Product Satisfaction (X2.2), and Rationality Price (X2.3) have significant measure product quality variables (X2). From the value of loading factor, it is known that the indicator price Rationality (X2.3) is the strongest indicator variable measuring product quality (X2).

At Corporate Image variable (X3) four indicators Attribute (X3.1), Functional (X3.2), Psychological (X3.3), and holistic / Imaginary (X3.4) have significant measure variables Corporate Image (X3). From the value of loading factor, it is known that the indicator Holistic (X3.4) is the strongest indicator variable measuring Corporate Image (X3).

In Customer Satisfaction variable (X4) both indicators Satisfaction with service (process) (X4.1), and Satisfaction with the cost (Result) (X4.2) have significant measure Customer Satisfaction variable (X4). From the value of loading factor, it is known that satisfaction with cost indicators (X4.2) is the strongest indicator variable measuring Customer Satisfaction (X4).

Customer Value in the variable (X5) Superiority of five indicators (X5.1), economies of scale (X5.2), Perfection (X5.3), passions (X5.4), and Benefits (X5.5) have significant value measured variables Customer (X5). From the value of loading factor, it is known that the indicator Benefit (X5.5) is the strongest indicator variable measuring customer value (X5).

Customer trust in the variable (X6) five indicators Length (X6.1), Reliability (X6.2), Hope (X6.3), superiority (X6.4) and Trust (x6.5) has significant measured variables Customer Trust (X6). From the value of 
loading factor, it is known that the indicator Hope (X6.3) is the strongest indicator variable measuring Customer Trust (X6).

Table 3. Value Factor Loading on Each Variable

\begin{tabular}{|c|c|c|c|c|c|c|}
\hline Indicator & \multicolumn{2}{|c|}{ X1 } & \multicolumn{2}{|c|}{$\mathbf{X} 2$} & \multicolumn{2}{|c|}{ X3 } \\
\hline 1 & X1.1 & $0.697 *$ & X2.1 & $0.594 *$ & X3.1 & $0.588^{*}$ \\
\hline 2 & $\mathrm{X} 1.2$ & $0.617 * *$ & $\mathrm{X} 2.2$ & $0.686^{*}$ & X3.2 & $0.644 *$ \\
\hline 3 & $\mathrm{X} 1.3$ & $0.537 *$ & $\mathrm{X} 2.3$ & $0.734 * *$ & X3.3 & $0.594 *$ \\
\hline 4 & X1.4 & $0.682 *$ & & & X3.4 & $0.661 * *$ \\
\hline 5 & $\mathrm{X} 1.5$ & $0.585^{*}$ & & & & \\
\hline Indicator & \multicolumn{2}{|c|}{$\mathrm{X} 4$} & \multicolumn{2}{|c|}{ X5 } & \multicolumn{2}{|c|}{ X6 } \\
\hline 1 & X4.1 & $0.736^{*}$ & X5.1 & $0.618 * *$ & X6.1 & $0.588^{*}$ \\
\hline 2 & $\mathrm{X} 4.2$ & $0.741 * *$ & X5.2 & $0.577 *$ & X6.2 & $0.624 *$ \\
\hline 3 & & & X5.3 & $0.621 *$ & X6.3 & $0.657^{*}$ \\
\hline 4 & & & X5.4 & $0.614 *$ & X6.4 & $0.591 *$ \\
\hline 5 & & & X5.5 & $0.642^{*}$ & X6.5 & $0.635 * *$ \\
\hline
\end{tabular}

Description: a $*$ stated p-value $<0.05$, and $* *$ states that fix

\subsection{Testing Results of Direct and Indirect Effect}

Hypothesis testing is done by testing the direct influence of CR (Critical Ratio) on each line direct effect partially. If the value of $C R>1.96$ or $\mathrm{P}$ value $<0.05$, we can conclude there is a significant effect, whereas if the value of $\mathrm{CR}<1.96$ or $\mathrm{P}$ values $>0.05$, it can be concluded there is no effect. The results of the full analysis, contained in the SEM analysis results, shown in Table 4 below presents the results of hypothesis testing effect (direct effect). The model results from the analysis of structural equational modeling (SEM) Table 4 looks there are 7 lines of 9 overall significant pathway, while two other lines are not significant. Corporate Image (Image) is directly influenced by the service quality (X1) and Product Quality (X2), customer value is directly influenced by the Product Quality, Customer Satisfaction directly influenced by the Service quality and Customer Value, Customer Trust affected directly by Corporate Image and Customer Satisfaction.

Table 4. Direct Effect Hypothesis Testing Results

\begin{tabular}{|c|c|c|c|c|}
\hline $\begin{array}{c}\text { Number } \\
\text { Hypothesis }\end{array}$ & Interpersonal Variables & Standardize & CR & P \\
\hline 1 & Service quality to the Corporate Image & 0.307 & 2.791 & $0.005^{*}$ \\
\hline 2 & Service quality to Customer Satisfaction & 0.307 & 2.597 & $0.009^{*}$ \\
\hline 3 & Product quality to the Corporate Image & 0.433 & 3.521 & $0.000^{*}$ \\
\hline 4 & Product quality to Customer Satisfaction & 0.149 & 1.100 & $0.271^{*}$ \\
\hline 5 & Product quality to Customer Value & 0.351 & 2.878 & $0.004^{*}$ \\
\hline 6 & Corporate Image to Customer Satisfaction & 0.154 & 1.144 & $0.253^{* *}$ \\
\hline 7 & Corporate Image to Customer Trust & 0.329 & 2.622 & $0.009^{*}$ \\
\hline 8 & Customer Value to Customer Satisfaction & 0.478 & 3.558 & $0.000^{*}$ \\
\hline 9 & Customer Satisfaction to Customer Trust & 0.408 & 3.072 & $0.002^{*}$ \\
\hline
\end{tabular}

Description: The * declared significant at $5 \%$ level, while a not significant stated $* *$

Based on testing of direct influence, from the ninth direct influence, there are two direct effects are not significant variables that influence product quality and corporate image to customer satisfaction. Therefore, testing the effect of not lamgsung. The test used the indirect effect of some direct influence test results. Indirect effect coefficient obtained from the product of the two or more coefficients directly influence the shape. Revealed a significant indirect effect if both the direct effect coefficient or all of the direct influence of the shape is significant. A complete directly influence the test results are presented in Table 5

Table 5. Research Hypothesis Testing Results Indirect Effects

\begin{tabular}{|c|c|c|c|c|}
\hline $\begin{array}{c}\text { Independent } \\
\text { Variable }\end{array}$ & $\begin{array}{c}\text { Dependent } \\
\text { Variable } \\
\end{array}$ & Intervening Variable & $\begin{array}{l}\text { Coefficient } \\
\text { Standardize }\end{array}$ & Description \\
\hline \multirow{2}{*}{ Service quality } & \multirow{2}{*}{ Customer Trust } & Corporate Image & 0.101 & Significant \\
\hline & & customer satisfaction & 0.125 & Significant \\
\hline Service quality & $\begin{array}{c}\text { customer } \\
\text { Satisfaction }\end{array}$ & Corporate Image & 0.047 & not significant \\
\hline \multirow{2}{*}{$\begin{array}{c}\text { Quality of } \\
\text { Product }\end{array}$} & \multirow{2}{*}{ Customer Trust } & Corporate Image & 0.142 & Significant \\
\hline & & customer satisfaction & 0.061 & not significant \\
\hline $\begin{array}{l}\text { Quality of } \\
\text { Product }\end{array}$ & $\begin{array}{c}\text { Customer } \\
\text { Satisfaction }\end{array}$ & Customer Value & 0.168 & Significant \\
\hline
\end{tabular}


From Table 5 shows that there are 4 of 7 significant indirect effects. The research hypothesis can also be presented in Chart 2 below:

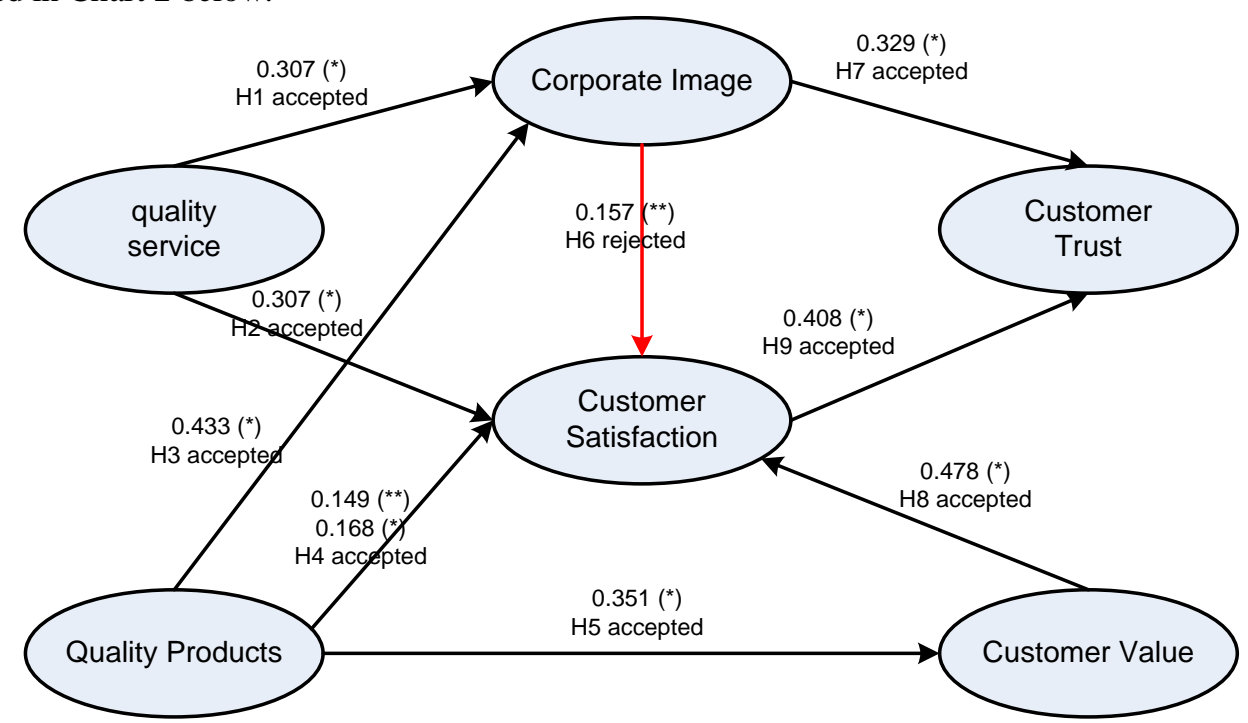

Graph 2. Summary of Hypothesis Testing Results

Path Analysis of Relationships Influence Service quality and Product quality to the Corporate Image, Customer Satisfaction, Customer Value and Customer Trust

\section{Results Discussion}

Based on the above results, it can be concluded some of the following:

The test results directly influence the service quality to the company's image, the value of the coefficient of the structural model (standardize) of 0.307, the value of Critical Ratio (CR) of 2.791 and 0.005 amounted to P. Because the value of CR $>1.96$, and $\mathrm{P}<0.05$, then the error rate of $5 \%$, the hypothesis is accepted. Conclusion of the receipt of this hypothesis proves that the higher service quality, the greater the company's image. Conversely the lower the quality of the service, the lower the image of the company.

The test results directly influence the service quality to customer satisfaction, the value of the coefficient of the structural model (standardize) of 0.307, the value of Critical Ratio (CR) of 2.597 and 0.009 amounted to P. Because the value of CR $>1.96$, and $\mathrm{P}<0.05$, then the error rate of $5 \%$, the hypothesis is accepted. Receipt of the second hypothesis of this study provide evidence that can support the theories and the results of previous studies that service quality has a positive influence on customer satisfaction. This suggests that the service quality and satisfaction is not an issue for customers Taplus BNI. The use of payroll for customers Taplus BNI is not a purely customer's decision, but the requirements that must be met for agencies where customers work, and family customers.

Testing three hypotheses about the effect on image quality of the products the Company obtained coefficient of 0.433 (positive) with CR of 3.521 and the p-value 0.000 has shown evidence that the regression coefficients obtained are significant. The results of this study are consistent with the theories and the results of previous studies showed evidence that the quality of the product on a particular customer's bank BNI Tabungan Plus (Taplus) does not give a good appreciation of the quality of the product. It shows that the product quality is not an issue for customers Taplus BNI. These results are also in line with the findings of the field that most of the customers in choosing Taplus BNI for their payroll needs, so they are less concerned about the quality of products received.

The test results directly influence the quality of the product to the customer value, the value of the coefficient of the structural model (standardize) of 0.351, the value of Critical Ratio (CR) of 2.878 and 0.004 amounted to P. Because the value of CR $>1.96$, and $\mathrm{P}<0.05$, then the error rate of $5 \%$, the hypothesis is accepted. If dlihat SEM analysis of the coefficient effect of product quality on customer value is derived from price rationality indicators. This means there is still enough room on the rationality of the price that needs to be repaired. This conclusion is supported by the findings of the field that some customers stating that the price or cost of the product Taplus BNI is still relatively high. Like for example the lowest cost and the balance amount that is greater than other bank products.

The test results directly influence the product quality to customer satisfaction, the value of the coefficient of the structural model (standardize) of 0.149, the value of Critical Ratio (CR) of 1.100 and 0.271 amounted to P. Because the value of $\mathrm{CR}<1.96$, and $\mathrm{P}>0.05$, then the error rate of $5 \%$, the hypothesis is 
rejected. That is, how high the quality of the product was, will not directly affect the level of customer satisfaction.

The test results do not directly influence the product quality to customer satisfaction through customer value, the value of the coefficient of the structural model (standardize) of 0.168. Both the direct influence of the shape it is significant. The indirect effect between product quality to customer satisfaction through customer value is significant. Accepted hypothesis 5 provides empirical evidence that the results of this study are consistent and support the theories and the results of previous studies. These results indicate that customers Taplus BNI provides a good appreciation of the quality of the product and the satisfaction received. This can be evidenced by the responses to all the indicators measuring product quality and customer satisfaction Taplus BNI maximum, although still on a high criteria.

The test results directly influence the corporate image on customer satisfaction, the value of the coefficient of the structural model (standardize) of 0.154, the value of Critical Ratio (CR) of 1.144 and 0.253 amounted to P. Because the value of $\mathrm{CR}<1.96$, and $\mathrm{P}>0.05$, then the error rate of $5 \%$, the hypothesis is rejected. That is, how high the image of the company was, will not directly affect the level of customer satisfaction. In connection corporate image on customer satisfaction, has no indirect effect. This is because in addition to BNI East Java as a government-owned bank, as well as never proven instances of abuse or cases BNI bank in East Java. Additionally respondents chose as customers Taplus BNI as well as state banks, the assessment of the image, security, and trust in the BNI to be very high.

The test results directly influence the corporate image of the customer's trust, the value of the coefficient of the structural model (standardize) of 0.329, the value of Critical Ratio (CR) of 2.622 and 0.009 amounted to P. Because the value of CR $>1.96$, and $\mathrm{P}<0.05$, then the error rate of $5 \%$, the hypothesis is accepted. Conclusion acceptance hypothesis 7 is supported by the finding that field with a very good appreciation of customers' corporate image corporate image resulting in a positive effect on customer trust have a small path coefficients.

The test results directly influence the customer value on customer satisfaction, the value of the coefficient of the structural model (standardize) of 0.478, the value of Critical Ratio (CR) of 3.558 and 0.000 amounted to $\mathrm{P}$. Because the value of $\mathrm{CR}>1.96$, and $\mathrm{P}<0.05$, then the error rate of $5 \%$, the hypothesis is accepted. The results obtained from field research on the two variables will be in the respondent response criteria have not been up to the high very positive. There is a good appreciation of both variables and the relationship between the two also indicates the possibility that the attributes of the indicators measuring the value and customer trust is a variable into consideration for customers.

The test results directly influence the customer satisfaction with customer trust, the value of the coefficient of the structural model (standardize) of 0.408, the value of Critical Ratio (CR) of 3.072 and 0002 amounted to P. Because the value of CR $>1.96$, and $\mathrm{P}<0.05$, then the error rate of $5 \%$, the hypothesis is accepted. These results show evidence that the higher the customer satisfaction, the higher the customer's trust.

With the characteristics of customers Taplus BNI described as above, the results of this study also concluded that most customers still require increased trust about the security, convenience, duration, Reliability, Hope, and Superiority.

\section{Conclusions And Recommendations}

Based on the above results, it can be concluded some of the following:

1. There is a significant effect between service quality to the company's image.

2. There is a significant effect between service quality to customer satisfaction.

3. There is a significant effect between product quality corporate image.

4. There is a significant indirect effect between product quality to customer satisfaction, through customer value.

5. There is a significant effect between product quality to customer value.

6. There were no significant effects between corporate image on customer satisfaction. That is, how high was the image of the company, will not directly affect the level of customer satisfaction.

7. There is a significant effect between corporate image on customers' trust.

8. There is a significant effect between customer value on customer satisfaction.

9. There is a significant effect between customer satisfactions to customer trust.

From the research results and conclusions obtained, it can be suggested:

1. It is expected that the bank BNI East Java to improve the physical displays, reliability, responsiveness, empathy employees, and security guarantees on products Tabungan Plus (Taplus) BNI East Java.

2. The existence of product breadth, Product Satisfaction and Rationality Price Tabungan Plus product (Taplus) BNI East Java. 
3. The need to increase satisfaction with the service (process), and satisfaction with cost (Result) Tabungan Plus product (Taplus) BNI East Java.

4. Superiority needed more attention, economies of scale, Perfection, passions, and Benefits Tabungan Plus products BNI East Java.

5. Improvement in duration, Reliability, Hope, superiority, and Trust Tabungan Plus customers BNI East Java.

6. Word of Mouth (attitude), and Purchase Intention (Behavior) Tabungan Plus customers BNI East Java

\section{References}

[1]. Abdullah, Dayang Nailul Munna Abang, and Francine Rozario. 2009. Influence of Service and Product Quality towards Customers Satisfaction: A Case Study at the Staff Cafetaria in the Hotel Industri,: World Academy of Science Enginering and Technology. 29(1): 185-190.

[2]. Amstrong, G And Kotler, P., 2006. Principles of Marketing. Prentice Hall. Inc. New York.

[3]. Aykkac, D. Selcen O. Aykac, Serkan Aydin, Metin Ates, and Ayse Tansel Cetin. 2008. Effects of service quality on customer satisfaction and customer loyalty: Marmae University Hospital. Electronic copy available at: http://ssm.com/abstract=1362601

[4]. Ba, Sulin and Wayne C. Johanson . 2008. An explanatory study of the impact of service process on online customer satisfaction,: Production and Operations management. 17(1): 107-119.

[5]. Brady, Michael, K. and J, Joseph Cronin. 2001. "Some Thoughts on Conceptualizing Perceived Service Quality: A Hierarchical Approach, Journal of Marketing 65(3): 34-49.

[6]. Brady, Michael, K and Christoper J. Robeertson, 2001. "Searching for a Concensus on the ancedent role of service Quality and Satisfaction: an Exploratory Cross National Study,: Journal of Business Research, 51(1): 53-60.

[7]. Cronin Jr, J. Joseph and Steven, A. Taylor. 1992. Measuring Service Quality: A Reexamiation and Extention, Journal of Marketing 56(3): 55-68.

[8]. Deng, Lu, Wei and Zang. 2009. Understanding customer satisfaction and loyalty: An empirical study of mobile instant message in China. International Journal of Information Management, 30(4): 289-300.

[9]. Elliot, Ray. 2000. The Leadership Industry and Using Leadership Research Effectively. MLQ Pty Ltd and BERU. Victoria University, Melbourne.

[10]. Engel J. F, Roger D. Balckwell dan Paul W. Miniard 1990, Consumer Behavior, Sixth Edition, Dryden Press. Chicago

[11]. Gronross C, 1993, Strategic Management and Marketing in the service Sector, Research reports / Swedish School of Economics and Business Administration

[12]. Gronross C, 1998, Marketing Service : the case of missing Product, Journal of Business \& Industrial Marketing 13(4/5): 322 - 338.

[13]. Hair JF. Jr., R. E. Amderson, R. LTatham, W.C. Black. 1998, Multivariate Data Analysis, Fifth Editionn Pretice Hall International.

[14]. Helgesen, Oyvind, Jon Ivar Havold, and Erik Nesset. (2010). Impact of store and chain image on the "Quality-satisfaction-loyalty process" ini petrol retailing. Journal of Retailing and Consumer Service 17(2010) 109-118.

[15]. Hessel (2003). The Effect of Corporate Image the Formation of Customer Loyalty: An Australian Replication, Australian Marketing Journal, 12(3).

[16]. Heung, V.C.S., Mole, C., Kwan, A. 1996. Brand Loyalty in Hotels; an Exploratory Study of Overseas Visitors to Hongkong, Australian Journal of Hospitally Management 1(1):1-11.

[17]. Hu. Hsin-Hui (Sunny) Hua, Jay Kandampully, and Tannika Devi Juwaheer. 2009. Relationships and impacts of service quality, perceived value ,costumer satisfaction and image: an empirical sudy. The Service Industries Journal 29(2): 111-125.

[18]. Hutchinson, Lai and Wang. 2009. Understanding the relationships of quality, value, equity, satisfaction and behavioral intentions among golf travelers. 30(2): 298-308

[19]. Ismail. Azman, Muhammad Madi bin Abdullah, Sebastian K. Francis. 2009. "Exploring the relationships among service quality features, perceived value and customer satisfaction. Journal of Industrial Engineering and Management. JIEM, 2(1): 230-250

[20]. Kamakura A. Wagner and Mittal, Vikas. 2000. "Satisfaction, Repurchase Intention and Repurchase Behavior: investigating the moderating Effect of Customer Characteristics,: Journal of Marketing Research 38(1): 131-142.

[21]. Kim. Changsu, Weihong Zhao, Kyung Hoon Yang. 2008. "An Empirical study on then integrater framework of e-CRM in online shopping: evaluating the relationships among perceived value, satisfaction and trust based on customers perspectives,: Journal of Electronic Commerce in Organizations 6(3) 1-19.

[22]. Kotler, P. 2000. Marketing Management, The Millenium ed, Upper Saddle River, Prentice - Hall, Inc. New Jersey.

[23]. Kumar. Archana and Heejin Lim. 2008. "Age differences in mobile service perceptions: comparison of generation Y and baby boomers,: Journal of Service Marketing. 22(7): 568-577. Emerald Group Publishing Limited.

[24]. Kuo Yen-Ku, and Kung-Don Ye. 2009. "The causal relationship between service quality, corporate image and adults learning satisfaction and loyalty: A Study of professional training programmes in a Taiwanese vocational institute,: Total Quality Management 20(7): 749-762.

[25]. Lai. Fujun, Mitch Griffin, Barry J. Babin. 2009. "How qulity, value, image and satisfaction create loyalty at a Chinese telecom,: Journal of Business Research 62(1) 980-986.

[26]. Lam, T., and H.Q. Zhang. 2003. Job Satisfaction and Organizational commitment in The Hongkong Fast Food Industry,: International Journal of Contemporary Hospital Management. 15(4): 214-220.

[27]. Meng, Juan. and Kevin J, Elliot. 2009. "Investigating Structural Relationships Between Service Quality, Switching Costs, and Customer Satisfaction,: Journal of Applied Business and Economics 9(2): 54-66.

[28]. Millbourn. G, Jr and Haight. T. G, 1998, A Primer on Quality Service, Quality Service Makes Happy Custuomers and Greater Profits, From Business Forum 23(3-4): 15-18.

[29]. Molinari. Lori K, Russel Abratt, and Paul Dion. 2008. "Satisfaction, quality and value and effects on repurchase and positive wordof-mouth behavioral intentions in a B2B service context,: Journal of Service Marketing 22(5): 363-373. Emerald Group Publishing Limited.

[30]. Naeem, Hummayoun, Asma Akram dan M Iqbal Saif Akram. 2009. Service quality and its impact on customer satisfaction,: An Empirical Business \& Economics Research Journal 8(12): 99.

[31]. Normann, R. 1991. Service Management: Strategy and Leadership in Service Business. John Wiley and Sons. New York.

[32]. O'Malley and Lisa. 1998. "Can Loyalty Schemes Really Build Loyalty?,: Journal of Marketing Intelligences \& Planing 16(1): 4755.

[33]. Owen, L and Othman, Q. A. 2002. “Adopting and Measuring Customer Service Quality (SQ) in Islamic Banks: A Case Study in Kuwait Finance House,: International Journal of Islamic Financial Service 3(4): 72-80. 
[34]. Parasuraman. A, Zithaml Valarie. A and Berry Leopard. L. 1985. "Conceptual Model of Service Quality and Implication for Future Research,: Journal of Marketing 49(1): 41-50.

[35]. Parasuraman. A, Zithaml Valarie. A and Berry Leopard. L. 1988. SERVQUAL: A Multi-Item Scale for Measuring Consumer Perceptions of Service Quality,: Journal of Retailing 65, No.(1): 12-36.

[36]. Parasuraman. A, Zithaml Valarie. A and Berry Leopard. L. 1993. "The Nature and Determinants of Customer Expectations of Service,: Journal of the Academy of Marketing Sciense 21(1): 1-12.

[37]. Parasuraman. A, Zithaml Valarie. A and Berry Leopard. L. 1995. Reassessment of Expectations as a Comparison Standard in Measuring Service Quality: Implications fo Further Research,: Journal of Marketing 58(2): 111-124.

[38]. Parker, Cathy and Brian P. Mathews, 2001, Customers Interpretations,: Journal of Marketing Intelligence \& Planning 19(1): 38-44.

[39]. Pollack, Birgit Leisen. 2009. Linking the hierarchical service quality model to customer satisfaction and loyalty, Journal of Services Marketing, 23(1): 42-50.

[40]. Qin. Hong and Victor R. Prybutok. 2008. "Determinants of Customer-perceived service quality in fast food restaurants and their relationship to customer satisfaction and behavioral intentions,: The Quality Management Journal 15(2): 35.

[41]. Ranaweera, C and Prabhu, J, 2003, On the Relative Importance of Customer Satisfaction and Trust as Determinants of Customer Retention and Positive Word of Mouth,: Journal of Targeting, Measurement and Analiysis for Marketing 12(1): 81-90.

[42]. Rangkuty, Freddy. 2002, Measuring Customer Satisfaction, Gramedia Pustaka Utama, Jakarta.

[43]. Robins, S. P. 2003. Organization Behavior, Tenth Edition. Prentice Hall. New York.

[44]. Sahadev. Sunil, and Keyoor Purani. 2008. Modelling the Consequences of e-service Quality. Marketing Intelligence \& Planning 26(6): 605-620. Emerald Group Publishing Limited.

[45]. Santoso, Singgih. 2002. SPSS Mengolah Data Statistik Secara Profesional. Versi 10. PT. Elex Media Komputindo - Kelompok Gramedia, Jakarta.

[46]. Sharma, Arun. and Thomas F. Stafford. 2000. "The Effect of Retail Atmospherics on Customers Perception of Sales People and Customer Persuasion: An Empirical Investigation,: Journal Of Business research. 49(2): 183-191.

[47]. Sirdeshmukh, D and Sinah, J. 2000. "Agency and Trust Mechanisms in Consumer Satisfaction and Loyalty Judgement,: Academy of Marketing Science Journal 28(1): 150-167.

[48]. Solimun, 2002. Structural Equation Modeling Lisrel dan AMOS, Fakultas MIPA Universitas Brawijaya. Malang.

[49]. Storbacka, K., Strandvik, T and Gronroos, C., 1999. "Managing Customer Relationships for profit: The Dinamics of Relationship Quality,: International Journal of Service Industry management 5(5): 21-38.

[50]. Taylor. Steven A. (2008).” Assessing then Use of Regression Analysis in Examining Service Recovery in the Insurance Industry: Relating Service Quality, Customer Satisfaction and Customer Trust. Journal of Insurance Issues 24(1 \& 2) 30-57.

[51]. Trasorras, Weinstein and Abratt. 2009. Value, satisfaction, Loyalty and retention in professional services,Journal of Marketing Intelligence \& Planning, 27(5): 615-632.

[52]. Vesel, Patrick and Zabkar, Vesna. 2009. Managing Customer Loyalty Through the Mediating Role of Satisfaction in the DIY Retail Program, Journal of Retailing and Customer Services, 16(5): 396-406.

[53]. Wang. Mei-Yu. 2008. "Measuring e-CRM service Quality In The Library Context: A Preliminary Study,: The electronic Library 26(6): 896-911.

[54]. Woodside, G. A. 1989. "Linking Service Quality, Customer Satisfaction and Behavioral Intention,: Journal of Health Care Marketing 9(4): 5-17.

[55]. Zeitaml. Valerie A. 1996. "The Behavioral Consequencies of service Quality,: Journal of Marketing 60(2): 31- 46.

[56]. Zeithaml, Valerie A and bitner, M. J. 1996. Service Marketing, Mc Graw-Hill International Editions, New York 